\title{
Trade in value added in the West Pacific: an input-output analysis
}

\author{
Yoichi Nakamura
}

Correspondence: yoichin@hosei.ac.jp Faculty of Science and Engineering, Hosei University, Koganei, Tokyo 184-8584, Japan

\section{Springer}

\begin{abstract}
The evolution of trade between the four regions in the West Pacific in both gross and value added terms is analyzed using international input-output tables. It is found that value added exports of computers and electronic equipment of the Asian economies are very limited in comparison with their gross exports, and that the largest shares of value added exports were accounted for by the services sectors in every region, particularly so in Japan and the US. Surpluses and deficits in bilateral trade balance in value added terms are generally lower than those in gross terms, and that Japan's manufacturing sector played a central role in the production chains in the West Pacific, and the US contributed to the region by providing services in value added terms. The inter-temporal factor decomposition of trade shows that deepening input-output linkages between the four regions played an important role in promoting trade in value added in the West Pacific. This process was partly interrupted by the economic turmoil during the 1995-2000 period, but intensified toward 2005. The service sectors seem to have played an increasingly important role in enhancing trade in value added in the West Pacific.

JEL codes: F14; F15

Keywords: Value added trade; Input-output table; Industrial linkage; Factor decomposition
\end{abstract}

\section{Background}

The recent trade literature has been increasingly focusing on trade in value added as against gross trade provided in official trade statistics. Foster-McGregor et al. [1], OECD-WTO [2] with the fragmentation of production processes across borders and the intensification of interconnectedness within supply chains, notably in East Asia, the importance of trade in intermediates has increased significantly in both goods and services trade. Hayakawa [3], Meng et al. [4], Miroudot et al. [5] official statistics on gross trade such as customsclearance statistics include both final products and intermediates. The picture given by gross trade can be quite different from that by trade in value added; since in today's production networks in East Asia, it is possible that the same intermediate goods and services are recorded many times as they go through customs. Value added generated by both domestic and foreign final demand, on the other hand, is more closely related with wages and employment, corporate profits, tax revenues, and finally national income. Data on gross exports and imports, however, are no less useful than before because they are indispensable to understand the technological structure of the cross-border production processes.

This study exploits a four region-country input-output system consisting of major Asian economies and the US, which builds upon the Asian International Input-Output Tables

(c) 2015 Nakamura. This is an Open Access article distributed under the terms of the Creative Commons Attribution License (http:// creativecommons.org/licenses/by/4.0), which permits unrestricted use, distribution, and reproduction in any medium, provided the original work is properly credited. 
(AIO) for 1995, 2000, and 2005 constructed by the Institute of Developing Economies. (Institute of Developing Economies [6-8]) Section 2 describes the analytical framework of this study to compare trade in gross terms and value-added terms in the four-region system and to make inter-temporal factor decomposition of trade in value added during the 1995-2005 decade. It also contains the construction of data. Section 3 presents the main results of the analysis. Section 4 concludes.

\section{Methods}

\subsection{Gross exports, value-added content of gross exports, and trade in value added}

The formulation of trade in value added and other trade measures in this subsection basically follows that presented in Koopman et al. [9].

Letting $n$ be the number of sectors, $A_{i j}$ be the $n \times n$ input coefficient matrix from region $i$ to region $j, X_{j}$ be the $n \times 1$ gross output vector of region $j, F_{i j}$ be the $n \times 1$ final demand vector of region $j$ supplied by region $i$, and $R_{j}$ be the $n \times 1$ net export vector of region $j$ to the rest of the world, this four-region system can be expressed as the following.

$$
\left[\begin{array}{l}
X_{1} \\
X_{2} \\
X_{3} \\
X_{4}
\end{array}\right]=\left[\begin{array}{llll}
A_{11} & A_{12} & A_{13} & A_{14} \\
A_{21} & A_{22} & A_{23} & A_{24} \\
A_{31} & A_{32} & A_{33} & A_{34} \\
A_{41} & A_{42} & A_{43} & A_{44}
\end{array}\right] \cdot\left[\begin{array}{l}
X_{1} \\
X_{2} \\
X_{3} \\
X_{4}
\end{array}\right]+\left[\begin{array}{l}
F_{11} \\
F_{21} \\
F_{31} \\
F_{41}
\end{array}\right]+\left[\begin{array}{l}
F_{12} \\
F_{22} \\
F_{32} \\
F_{42}
\end{array}\right]+\left[\begin{array}{l}
F_{13} \\
F_{23} \\
F_{33} \\
F_{43}
\end{array}\right]+\left[\begin{array}{l}
F_{14} \\
F_{24} \\
F_{34} \\
F_{44}
\end{array}\right]+\left[\begin{array}{l}
R_{1} \\
R_{2} \\
R_{3} \\
R_{4}
\end{array}\right]
$$

Fixing or neglecting net exports to the rest of the world, $R_{j} s$, for simplicity,

(1) is solved for the gross output as,

$$
\left[\begin{array}{l}
X_{1} \\
X_{2} \\
X_{3} \\
X_{4}
\end{array}\right]=\left[\begin{array}{cccc}
I-A_{11} & -A_{12} & -A_{13} & -A_{14} \\
-A_{21} & I-A_{22} & -A_{23} & -A_{24} \\
-A_{31} & -A_{32} & I-A_{33} & -A_{34} \\
-A_{41} & -A_{42} & -A_{43} & I-A_{44}
\end{array}\right]^{-1} \cdot\left[\begin{array}{l}
F_{11}+F_{12}+F_{13}+F_{14} \\
F_{21}+F_{22}+F_{23}+F_{24} \\
F_{31}+F_{32}+F_{33}+F_{34} \\
F_{41}+F_{42}+F_{43}+F_{44}
\end{array}\right]
$$

In this four-region system, generation and absorption of value added can be described as

$$
\begin{aligned}
\hat{V} B F= & {\left[\begin{array}{cccc}
\hat{V}_{1} & \hat{V}_{2} & & \\
& & \hat{V}_{3} & \\
0 & \hat{V}_{4}
\end{array}\right] \cdot\left[\begin{array}{llll}
B_{11} & B_{12} & B_{13} & B_{14} \\
B_{21} & B_{22} & B_{23} & B_{24} \\
B_{31} & B_{32} & B_{33} & B_{34} \\
B_{41} & B_{42} & B_{43} & B_{44}
\end{array}\right] \cdot\left[\begin{array}{llll}
F_{11} & F_{12} & F_{13} & F_{14} \\
F_{21} & F_{22} & F_{23} & F_{24} \\
F_{31} & F_{32} & F_{33} & F_{34} \\
F_{41} & F_{42} & F_{43} & F_{44}
\end{array}\right] } \\
= & {\left[\begin{array}{llll}
\hat{V}_{1} \sum B_{1 k} F_{k 1} & \hat{V}_{1} \sum B_{1 k} F_{k 2} & \hat{V}_{1} \sum B_{1 k} F_{k 3} & \hat{V}_{1} \sum B_{1 k} F_{k 4} \\
\hat{V}_{2} \sum B_{2 k} F_{k 1} & \hat{V}_{2} \sum B_{2 k} F_{k 2} & \hat{V}_{2} \sum B_{2 k} F_{k 3} & \hat{V}_{2} \sum B_{2 k} F_{k 4} \\
\hat{V}_{3} \sum B_{3 k} F_{k 1} & \hat{V}_{3} \sum B_{3 k} F_{k 2} & \hat{V}_{3} \sum B_{3 k} F_{k 3} & \hat{V}_{3} \sum B_{3 k} F_{k 4} \\
\hat{V}_{4} \sum B_{4 k} F_{k 1} & \hat{V}_{4} \sum B_{4 k} F_{k 2} & \hat{V}_{4} \sum B_{4 k} F_{k 3} & \hat{V}_{4} \sum B_{4 k} F_{k 4}
\end{array}\right], }
\end{aligned}
$$

where $\hat{V}_{j}$ is the $n \times n$ diagonal value-added ratio matrix whose $(k, k)$ element is defined as $1-\sum_{i=1}^{4} \sum_{l=1}^{n} A_{i j}(l, k)$, and $B_{i j}$ is the $n \times n$ block Leontief inverse matrix in Eq. 2. $\hat{V}_{i} \sum B_{i k} F_{k j}$ in the last matrix of Eq. 3 represents the $n \times 1$ vector of value added generated in region $i$ and is absorbed by final demand in region $j$ through direct imports from region $i$ and indirect imports from region $i$ via third regions within the four-region system. Thus the off-diagonal elements of the last matrix of Eq. 3 represent value-added exports and the diagonal ones represent 
domestically consumed value added. Meanwhile, the $n \times 1$ gross export vector from region $i$ to region $j$ is expressed as

$$
E_{i j}=A_{i j} X_{j}+F_{i j}(i \neq j)
$$

and letting $E_{i}=\sum_{k \neq i} E_{i k}$,

$$
\hat{V} B\left[\begin{array}{cccc}
E_{1} & 0 & 0 & 0 \\
0 & E_{2} & 0 & 0 \\
0 & 0 & E_{3} & 0 \\
0 & 0 & 0 & E_{4}
\end{array}\right]=\left[\begin{array}{cccc}
\hat{V}_{1} B_{11} E_{1} & \hat{V}_{1} B_{12} E_{2} & \hat{V}_{1} B_{13} E_{3} & \hat{V}_{1} B_{14} E_{4} \\
\hat{V}_{2} B_{21} E_{1} & \hat{V}_{2} B_{22} E_{2} & \hat{V}_{2} B_{23} E_{3} & \hat{V}_{2} B_{24} E_{4} \\
\hat{V}_{3} B_{31} E_{1} & \hat{V}_{3} B_{32} E_{2} & \hat{V}_{3} B_{33} E_{3} & \hat{V}_{3} B_{34} E_{4} \\
\hat{V}_{4} B_{41} E_{1} & \hat{V}_{4} B_{42} E_{2} & \hat{V}_{4} B_{43} E_{3} & \hat{V}_{4} B_{44} E_{4}
\end{array}\right]
$$

yields value-added content of gross exports. Diagonal elements of Eq. 5 give the domestic value added contained in each region's gross exports. Off-diagonal elements give the foreign value added contained in each region's exports.

\subsection{Inter-temporal decomposition of changes in trade in value added}

Changes in trade in value added defined in Eq. 3 can be decomposed into those due to changes in final demand $F=\left\{F_{i j}\right\}$ and changes in the structural parameters $\hat{V}$ and $A=\left\{A_{i j}\right\}$ in the following manner, which is similar to the standard growth factor decomposition proposed by Chenery and Sylquin [10]. Letting superscripts denote periods 1 and 2,

$$
\Delta V A T=\hat{V}^{2} B^{2} F^{2}-\hat{V}^{1} B^{1} F^{1}=\hat{V}^{2} B^{2} \Delta F+\hat{V}^{2} B^{2} \Delta A X^{1}+\Delta \hat{V} X^{1}
$$

where $X^{1}=B^{1} F^{1}$. The first term of the rightmost hand of Eq. 6 represents changes in trade in value added due to increases in final demand $(\Delta F)$ of the endogenous regions (the final demand factor). The second term gives effects of the intensification of intermediate input relations $(\Delta A)$ between the regions (the input coefficient factor). And the third term represents changes due to variations in value-added ratios $(\Delta \hat{V})$ in the sectors of each region ( the value-added ratio factor).

Equation 6 is the expression in terms of the structural parameters in period 2 and outputs in period 1. Decomposition can also be made in terms of the structural parameters in period 1 and outputs in period 2. A simple average of the two is taken to present the results of this decomposition in this study.

\subsection{Data}

The ten endogenous economies of AIO are aggregated into four regions: the NIESASEAN region or Asia 7 (Indonesia, Malaysia, the Philippines, Singapore, Thailand, Taiwan and Korea), China, Japan and the United States.

With respect to sectoral aggregation, 76 sectors of AIO (78 sectors of the 1995 table) are aggregated into 22 sectors which are shown in the Additional file 1. Imports of intermediate and final products from the exogenous regions are added on domestic intermediate inputs and domestic supply of final demand, and they are, at the same time, subtracted from net exports to the rest of the world. In other words, while imports from the endogenous regions are treated as non-competitive ones, imports from the exogenous regions are treated as being competitive. 
Table 1 Gross exports and trade balance between four regions

\begin{tabular}{|c|c|c|c|c|c|c|c|c|c|}
\hline & \multirow[b]{2}{*}{ From/to } & \multicolumn{4}{|c|}{ Gross exports (mil. US dollars) } & \multicolumn{4}{|c|}{ Trade balance (mil. US dollars) } \\
\hline & & Asia 7 & China & Japan & US & Asia 7 & China & Japan & US \\
\hline \multirow[t]{4}{*}{ (1) 1995} & Asia 7 & 0 & 23,674 & 71,119 & 109,236 & & 5837 & $-59,773$ & 25,620 \\
\hline & China & 17,837 & 0 & 31,741 & 25,550 & -5837 & & 4126 & 10,939 \\
\hline & Japan & 130,892 & 27,615 & 0 & 120,476 & 59,773 & -4126 & & 50,430 \\
\hline & US & 83,616 & 14,611 & 70,046 & 0 & $-25,620$ & $-10,939$ & $-50,430$ & \\
\hline \multirow[t]{4}{*}{ (2) 2000} & Asia 7 & 0 & 60,973 & 84,736 & 149,558 & & 31,451 & $-35,476$ & 64,456 \\
\hline & China & 29,522 & 0 & 44,904 & 72,547 & $-31,451$ & & 10,437 & 53,201 \\
\hline & Japan & 120,212 & 34,467 & 0 & 134,868 & 35,476 & $-10,437$ & & 68,766 \\
\hline & US & 85,102 & 19,345 & 66,101 & 0 & $-64,456$ & $-53,201$ & $-68,766$ & \\
\hline \multirow[t]{4}{*}{ (3) 2005} & Asia 7 & 0 & 175,258 & 116,858 & 173,316 & & 79,363 & $-42,187$ & 55,348 \\
\hline & China & 95,895 & 0 & 109,799 & 194,369 & $-79,363$ & & 13,639 & 151,848 \\
\hline & Japan & 159,046 & 96,160 & 0 & 136,159 & 42,187 & $-13,639$ & & 65,031 \\
\hline & US & 117,968 & 42,522 & 71,128 & 0 & $-55,348$ & $-151,848$ & $-65,031$ & \\
\hline
\end{tabular}

\section{Results and discussion}

\subsection{Gross trade and trade in value added}

Table 1 shows gross exports of both intermediate and final goods and services between the four regions. It also presents bilateral trade balance in gross terms. Within Asia, Asia 7 had bilateral trade deficits with Japan. Japan had deficits with China, which in turn had deficits with Asia 7. All the three regions of Asia had surpluses with the US. During the 10-year period since 1995, China ballooned its surpluses with the US, while, at the same time, enlarging deficits with Asia 7.

Table 2 decomposes gross exports of the four regions by geographical source of value added using Eq. 5. The diagonal elements of the table give domestically produced value

Table 2 Value-added content shares in gross exports of four regions

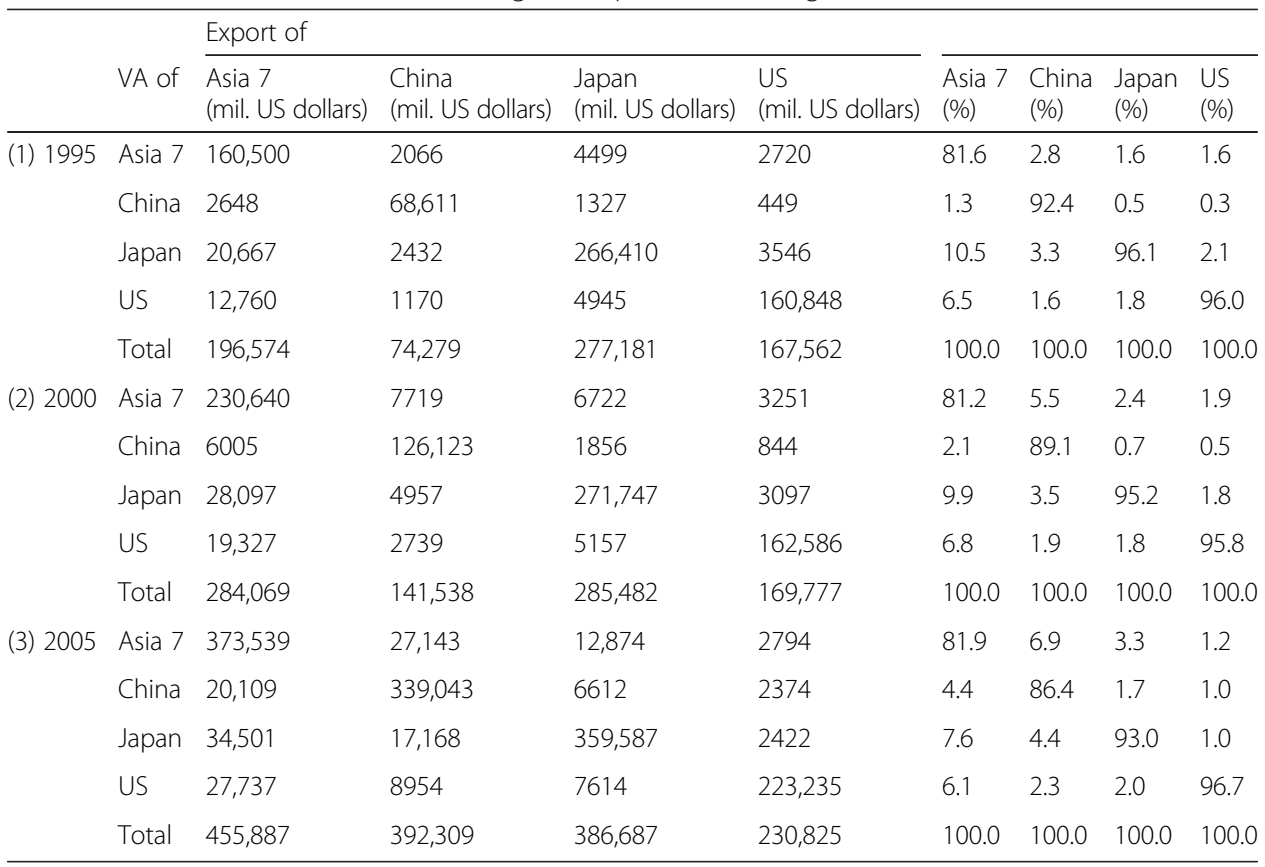


added contained in gross exports, while the off-diagonal elements represent foreign value added embodied in gross exports.

Domestic value added occupied more than $80 \%$ of gross exports of all regions for all years. The share of domestic value added was relatively low for Asia 7 and remained stable. Japan lost its share slightly in Asia 7's value-added content, while China raised its share. Both China and Japan lost about 3 percentage points in their domestic valueadded shares during the 10-year period, with the losses being covered by the other Asian trading partners. There were no significant changes in the value-added composition of gross exports of the US. This is probably because cross-border transactions of the US in North America are not dealt with in this analysis.

Table 3 shows trade in value added between the four regions, derived by zeroing the diagonal elements of Eq. 3. The signs of bilateral trade balances of value added are the same as those in Table 1 for gross exports. Surpluses and deficits in bilateral trade balance in value-added terms are generally lower than those in gross terms in absolute values, significantly so in some cases; Asia 7's surplus with China and Japan's surplus with Asia 7 were markedly lower in value-added terms than in gross terms. However, Japan's surplus with the US was larger in value-added terms in all years, and this also applies to Asia 7's surplus with the US in 2005. This implies that Japan and Asia 7, presumably NIES in particular, exported their value added in significant amount to the US through indirect trade via third parties.

Johnson and Noguera [11] find, using GTAP data for 2004, the US-China deficit was approximately 30-40 \% lower on a value-added basis than on gross trade basis, while the US-Japan deficit was about 33 \% larger. The findings in this study are qualitatively consistent with those, but the differences between the two concepts are much smaller. Koopman et al. [9] report that China's trade balance with Japan switches from a surplus in gross terms to a deficit in value-added terms. In this study, however, the balance is found to have been in deficits in both terms.

Comparison of gross exports and value-added exports can also be made for exports of individual sectors of each region. Fig. 1 shows gross exports and value-added exports

Table 3 Trade in value added and balance between four regions

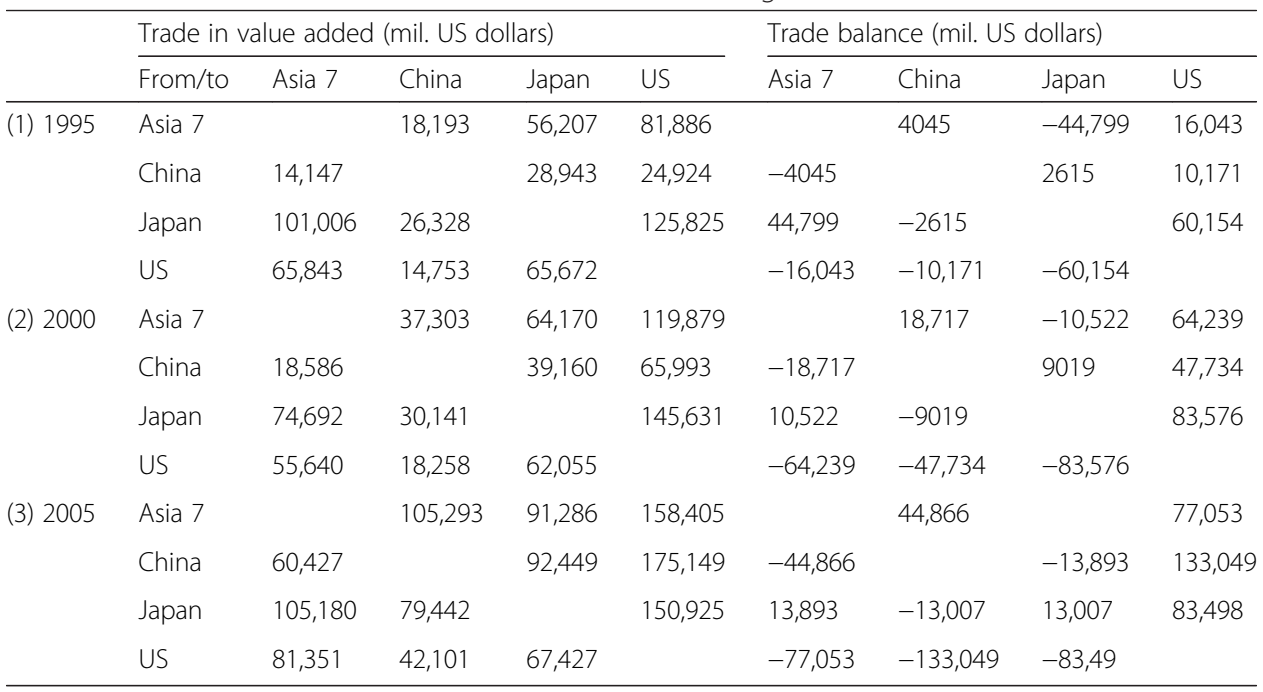




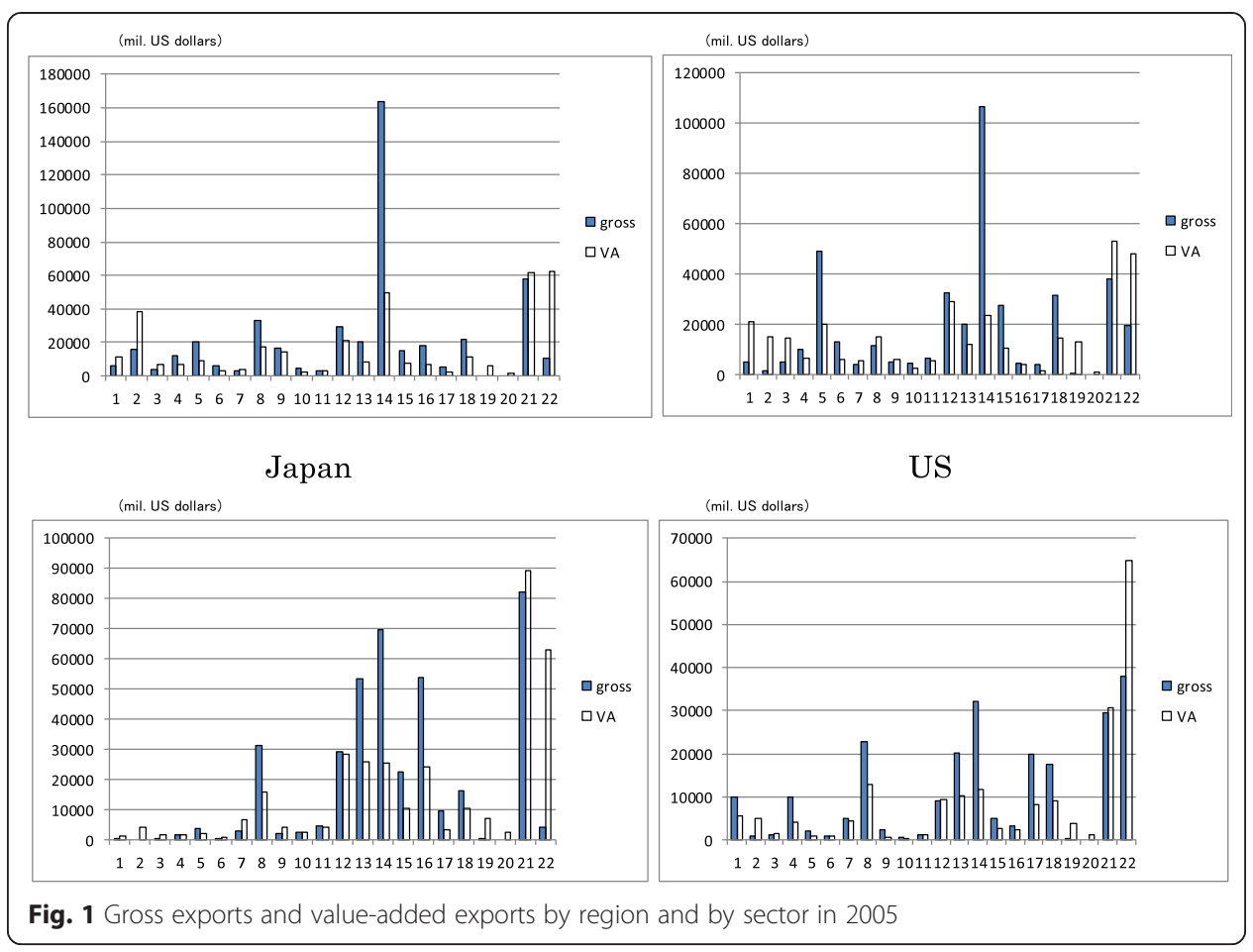

of 22 sectors of the four regions in 2005 . The charts for 1995 and 2000 offer essentially the same picture as for 2005, hence are omitted.

Asia 7 and China reveal very similar patterns. Compared with large gross exports of computers and electronic equipment (sector 14), value-added exports of the sector were rather limited. Trade and transport (21) and other services (22) accounted for the largest shares in value-added exports of Asia 7 and China, but not to the extent of exports of Japan and the US. Crude petroleum and natural gas (2) of Asia 7 and metal and metal products (12) of China had relatively large value-added exports.

In the case of Japan, the largest contributor was trade and transport (21) both in gross and value-added terms. It was followed by other services (22) in value-added terms. Its gross exports, however, were negligibly small. In contrast, the US's other services sector accounted for the largest share in both gross and value-added terms. Japan's material and machinery manufacturing sectors (chemical products (8), metal and metal products (12), industrial machinery (13), computers and electronic equipment (14), motor vehicles (16)) generally contributed larger shares both in gross and value-added terms than their US counterparts. It may be said that, while Japan's manufacturing sector played a central role in the production chains in the West Pacific, the US contributed to the region by providing services, in value-added terms in particular. Dean et al. [12] suggest the same role of Japan's manufacturing sector using China's customs statistics.

Japan was running larger trade surpluses with Asia 7 in gross terms than in valueadded terms, while opposite relations are observed in its trade surpluses with the US. In order to investigate into this difference, bilateral trade balance of Japan by sector in 2005 with the two regions is shown in Fig. 2. Japan had large gross deficits and even larger value-added deficits with Asia 7 in crude petroleum and natural gas (2). It also had significant value-added deficits with Asia 7 in agriculture, forestry and fishery (1), 


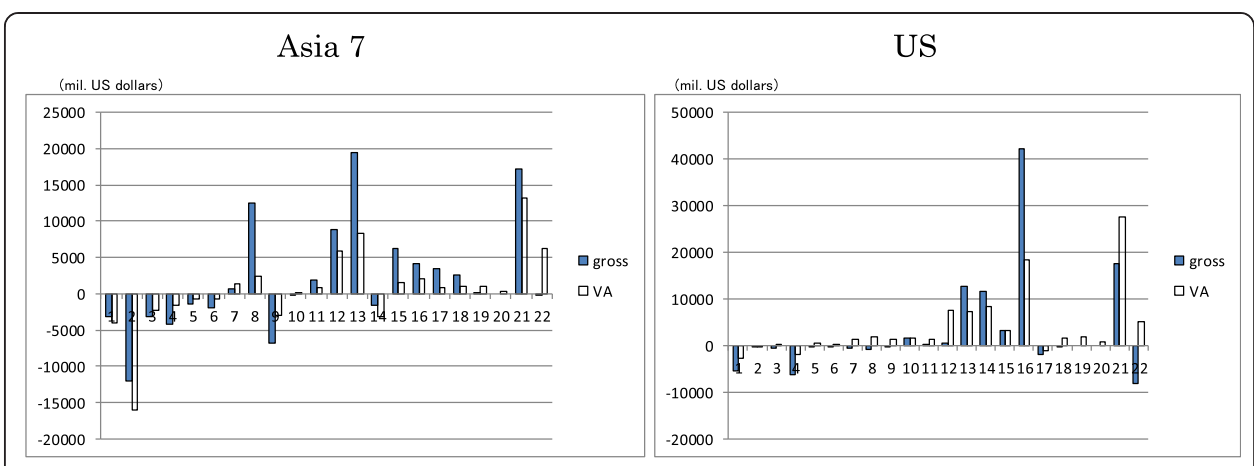

Fig. 2 Trade balance of Japan with Asia 7 and US in 2005

petroleum and petroleum products (9), and computer and electronic equipment (14), while having surpluses in industrial machinery (13), trade and transport (21), and other services (22). Deficits in energy-related sectors contributed to lower overall valueadded surpluses of Japan with Asia 7.

With respect to trade balance between Japan and the US, Japan's surpluses in two service sectors contributed to higher value-added surpluses than gross surpluses. Value-added surpluses in trade and transport (21) were significantly larger than gross surpluses. Moreover, the balance in other services (22) was positive in value-added terms while it was negative in gross terms. This reversal was due to indirect exports of other services through exports of manufactured goods. Six Japanese manufacturing sectors had larger value-added surpluses than gross ones. They were pulp, paper and printing (7), chemical products (8), petroleum and petroleum products (9), rubber products (10), nonmetallic mineral products (11), and metals and metal products (12). Their surpluses were not large but not negligible either. Value added of these sectors, together with that of the service sectors, was embodied in Japan's major export products such as industrial machinery (13), computer and electronic equipment (14), and motor vehicles (16).

\subsection{Changes in trade in value added during the 1995-2005 decade}

Table 4 presents the results of the inter-temporal decomposition of changes in trade in value added between the four regions based on Eq. 6. The decomposition was conducted for the decade of this analysis and the two 5-year sub-periods.

As the first panel of Table 4 shows, Asia 7 and China increased their total value-added exports tremendously in the West Pacific during the 1995-2005 decade. Increases in trade between Asia 7, China, and the US are particularly notable. While increases in final demand were the driving force of the export generation (the final demand factor), intensified input-output relations between the regions also contributed to increases in trade in value added (the input coefficient factor). Increases in inter-regional input coefficients translated into lower value-added ratios, which worked negatively on value-added transaction (the value-added ratio factor). Note should be taken, however, that the sum of the input coefficient factor and the value-added ratio factor was generally positive.

Japan's value-added trade with the other regions behaved somewhat differently. Changes in Japan's final demand reduced imports from Asia 7 and the US, and, judging from the input coefficient factor, Japan's industrial linkages with Asia 7 and the US rather weakened. During the decade, intermediate inputs from Japan's computer and 
Table 4 Inter-temporal decomposition of changes in trade in value added

\begin{tabular}{|c|c|c|c|c|c|c|c|c|c|}
\hline & \multicolumn{5}{|c|}{ Total changes (mil. US dollars) } & \multicolumn{4}{|c|}{ Final dem and factor (mil. US dollars) } \\
\hline & From/to & Asia 7 & China & Japan & US & Asia 7 & China & Japan & US \\
\hline \multirow[t]{12}{*}{ (1) 1995-2005 } & Asia 7 & & 87,100 & 35,080 & 76,518 & & 62,132 & -3040 & 69,082 \\
\hline & China & 46,279 & & 63,506 & 150,226 & 22,674 & & 36,575 & 109,145 \\
\hline & Japan & 4174 & 53,114 & & 25,100 & 15,244 & 53,745 & & 53,584 \\
\hline & US & 15,508 & 27,348 & 1755 & & 9302 & 26,406 & $-12,972$ & \\
\hline & \multicolumn{5}{|c|}{ Input coefficient factor (mil. US dollars) } & \multicolumn{4}{|c|}{ Value-added ratio factor (mil. US dollars) } \\
\hline & From/to & Asia 7 & China & Japan & US & Asia 7 & China & Japan & US \\
\hline & Asia 7 & & 34,956 & 47,953 & 26,004 & & -9987 & -9833 & $-18,568$ \\
\hline & China & 29,680 & & 36,114 & 59,870 & -6074 & & -9182 & $-18,789$ \\
\hline & Japan & -1309 & 4675 & & $-13,950$ & -9761 & -5306 & & $-14,534$ \\
\hline & US & 9602 & 2283 & 17,955 & & -3396 & -1341 & -3228 & \\
\hline & \multicolumn{5}{|c|}{ Total changes (mil. US dollars) } & \multicolumn{4}{|c|}{ Final dem and factor (mil. US dollars) } \\
\hline & From/to & Asia 7 & China & Japan & US & Asia 7 & China & Japan & US \\
\hline \multirow[t]{12}{*}{ (2) 1995-2000 } & Asia 7 & & 19,110 & 7963 & 37,992 & & 8400 & -2311 & 33,153 \\
\hline & China & 4439 & & 10,217 & 41,069 & 680 & & 6760 & 32,716 \\
\hline & Japan & $-26,314$ & 3812 & & 19,806 & $-17,792$ & 4186 & & 35,381 \\
\hline & US & $-10,203$ & 3506 & -3617 & & -7831 & 4054 & -5408 & \\
\hline & \multicolumn{5}{|c|}{ Input coefficient factor (mil. US dollars) } & \multicolumn{4}{|c|}{ Value-added ratio factor (mil. US dollars) } \\
\hline & From/to & Asia 7 & China & Japan & US & Asia 7 & China & Japan & US \\
\hline & Asia 7 & & 13,034 & 15,094 & 15,410 & & -2324 & -4820 & $-10,571$ \\
\hline & China & 5165 & & 5968 & 13,067 & -1406 & & -2511 & -4713 \\
\hline & Japan & -7326 & 42 & & $-13,338$ & -1196 & -416 & & -2237 \\
\hline & US & -2453 & -631 & 1231 & & 81 & 82 & 560 & \\
\hline & \multicolumn{5}{|c|}{ Total changes (mil. US dollars) } & \multicolumn{4}{|c|}{ Final dem and factor (mil. US dollars) } \\
\hline & From/to & Asia 7 & China & Japan & US & Asia 7 & China & Japan & US \\
\hline \multirow[t]{10}{*}{ (3) 2000-2005 } & Asia 7 & & 67,990 & 27,116 & 38,526 & & 60,176 & 1109 & 37,832 \\
\hline & China & 41,841 & & 53,290 & 109,157 & 23,481 & & 30,658 & 70,489 \\
\hline & Japan & 30,488 & 49,302 & & 5294 & 31,244 & 49,611 & & 17,849 \\
\hline & US & 25,712 & 23,842 & 5372 & & 16,670 & 22,945 & -6627 & \\
\hline & \multicolumn{5}{|c|}{ Input coefficient factor (mil. US dollars) } & \multicolumn{4}{|c|}{ Value-added ratio factor (mil. US dollars) } \\
\hline & From/to & Asia 7 & China & Japan & US & Asia 7 & China & Japan & US \\
\hline & Asia 7 & & 12,065 & 29,790 & 7919 & & -4250 & -3783 & -7225 \\
\hline & China & 21,305 & & 27,574 & 48,968 & -2945 & & -4943 & $-10,301$ \\
\hline & Japan & 6363 & 4274 & & 519 & -7119 & -4583 & & $-13,075$ \\
\hline & US & 12,506 & 2377 & 15,549 & & -3464 & -1480 & -3550 & \\
\hline
\end{tabular}

electronic equipment (14) and motor vehicles (16) sectors to their counterparts in Asia 7 and the US were replaced by domestic supplies, reflecting the increasing localization of production overseas by Japanese multinationals.

The second and third panels of Table 4 split the changes in the decade into those in two 5-year periods: 1995 to 2000 and 2000 to 2005. Excepting for the value-added ratio factor subpanels, all entries in the second period are positive with one exception, while about one third of entries in the first period are negative. 
During the first period, many of the Asia 7 economies were undergoing financial and currency crises. Their currencies depreciated drastically, which promoted exports to the US through the final demand factor and to China, Japan, and the US through the input coefficient factor. China, which had devalued its currency beforehand, increased its value-added exports steadily during the first period. Exports of Japan and the US to Asia 7 were reduced significantly through both the final demand and input coefficient factors.

During the second period, trade in value added was enhanced steadily between the four regions. China's value-added exports to the US increased more than 109 billion dollars during the period. Exchanges of value added between Asia 7 and China and between China and Japan increased considerably. After experiencing the economic turmoil and recovery during the first period, the second period saw a comeback to the process of deepening economic and industrial linkages in the West Pacific.

\section{Conclusions}

In this study, the evolution of trade between the four regions in both gross and valueadded terms is analyzed. Among the major findings are that value-added exports of computers and electronic equipment of Asia 7 and China were very limited in comparison with their gross exports and that the largest shares of value-added exports were accounted for by the services sectors in every region, particularly so in Japan and the US.

Surpluses and deficits in bilateral trade balance in value-added terms were generally lower than those in gross terms in absolute values. However, Japan's surpluses with the US were larger in value-added terms than in gross terms, reflecting the fact that value added of the material-related manufacturing sectors, together with that of the service sectors, was embodied in Japan's major export products (e.g., steel in motor vehicles) to the US. Overall, it can be said that Japan's manufacturing sector played a central role in the production chains in the West Pacific, and the US contributed to the region by providing services, particularly in value-added terms.

The inter-temporal factor decomposition of trade in value added reveals that increases in final demand in the regions and deepening input-output linkages between the regions played an important role in promoting trade in value added in the West Pacific. But the process was by no means smooth and stable. After experiencing partial but substantial retreats towards the end of the twentieth century, the process of deepening economic and industrial linkages in the West Pacific resumed in the twenty-first century.

Major findings of this study seem to suggest an increasingly important role played by the service sectors in enhancing trade in value added. Our future agenda should include the analysis of the contribution of the service sectors, in more detail, to the development of cross-border industrial linkages in the West Pacific.

\section{Additional file}

Additional file 1: Sector classification of the input-output tables. 
Received: 7 November 2014 Accepted: 24 April 2015

Published online: 10 June 2015

\section{References}

1. Forter-McGregor N, Stehrer R. Value added content of trade: a comprehensive approach. Econ Lett. 2013;120:354-7.

2. OECD-WTO. Trade in value added: concepts, methodologies and challenges, www.oecd.org/sti/ind/49894138.pdf. 2012.

3. Hayakawa K. Growth of intermediate goods trade in East Asia. Pac Econ Rev. 2007;12(4):511-23.

4. Meng B, Yamano N, Webb C. Application of factor decomposition techniques to vertical specialization measurements, IDE Discussion Paper 276. 2011

5. Miroudot S, Lanz R, Ragoussis A. Trade in intermediate goods and services, OECD Trade Policy Working Paper 93. 2009.

6. Institute of Developing Economies. Asian International Input-Output Table 1995. 2001.

7. Institute of Developing Economies. Asian International Input-Output Table 2000. 2006.

8. Institute of Developing Economies. Asian International Input-Output Table 2005. 2013.

9. Koopman R, Powers W, Wang Z, Wei S-J. Give credit to where credit is due: tracing value added in global production chains, NBER Working Paper Series 16426. 2011

10. Chenery HB, Sylquin M. A comprehensive analysis of industrial growth. In: Mathews RCO, editor. Economic Growth and Resources. New York: Macmillan; 1979.

11. Johnson RC, Noguera G. Accounting for intermediates: production sharing and trade in value added. J Int Econ. 2012;86:224-36.

12. Dean JM, Lovely ME, Mora J. Decomposing China-Japan-US trade: vertical specialization, ownership, and organizational form. J Asian Econ. 2009;20:596-610.

Submit your manuscript to a SpringerOpen ${ }^{\circ}$ journal and benefit from:

- Convenient online submission

- Rigorous peer review

- Immediate publication on acceptance

- Open access: articles freely available online

- High visibility within the field

- Retaining the copyright to your article 